\title{
THE IMPACT OF \\ MACROECONOMIC ON NONPERFORMING LOAN: COMPARISON STUDY AT CONVENTIONAL AND ISLAMIC BANKING
}

\section{Dedi Kusmayadi}

dieks68@yahoo.com

Irman Firmansyah,

irmanfirmansyah@unsil.ac.id

Jajang Badruzaman

jajangbadruzaman@unsil.ac.id

Lecturer at Accounting Department of Economics Faculty of Siliwangi University

\section{Abstrak}

Rata-rata rasio NPF bank syariah lebih tinggi dibandingkan NPL bank konvensional. Hal ini menjadi fenomena yang harus diteliti dan diindikasikan terdapat faktor- 
faktor yang mempengaruhinya khususnya faktor makroekonomi. Penelitian bertujuan untuk membandingkan faktor-faktor yang mempengaruhi non performing loan (NPL) pada perbankan konvensional dan perbankan syariah. Beberapa variabel makroekonomi yang diduga mempengaruhi NPL/NPF adalah SBI/SBIS, BI rate, nilai tukar, inflasi, GDP dan variabel kontrol yaitu efisiensi. Periode penelitian dari Maret 2010 sampai Desember 2016 dengan data triwulanan. Analisis menggunakan regresi linier berganda. Hasil penelitian menunjukkan bahwa dari seluruh variabel makroekonomi hanya SBIS, inflasi dan PDB yang berpengaruh negatif signifikan terhadap NPF bank syariah. Sedangkan hanya PDB yang berpengaruh terhadap NPL bank konvensional.

Dengan demikian hanya bank syariah yang merasakan dampak dari makroekonomi khususnya SBIS, inflasi dan PDB sehingga hasil ini dapat menjadi dasar bagi Bank Indonesia dan pemerintah dalam membuat kebijakan makroekonomi.

Kata Kunci: NPL, NPF, makroekonomi, perbankan

\section{Abstract}

The average NPF ratio of Islamic banks is higher than NPL of the conventional bank. This becomes a phenomenon that must be examined and indicated there are factors that influence macroeconomic factors in particular. This study aims to compare factors affecting nonperforming loan (NPL) in conventional banking and Islamic banking. Some macroeconomic variables that are suspected to affect NPL/NPF are BIC/SBIC, BI rate, exchange rate, inflation, GDP, and control variable is efficiency. The study period from March 2010 to December 2016 with quarterly data. The analysis used multiple linear regression. The results showed that of all macroeconomic variables only SBIC, inflation and GDP has a significant negative effect on NPF Islamic 
bank. While only GDP has a significant negative effect on NPL conventional bank. Thus only Islamic banks are feeling the impact of macroeconomics especially SBIC, inflation and GDP so that these results can be the basis for Bank Indonesia and the government in making macroeconomic policy.

Keywords: NPL, NPF, macroeconomic, banking 


\section{INTRODUCTION}

Bank has a very strategic position in the Indonesian economy. as an intermediary, the bank works to help people with excess funds to be stored and channeled back to the people that are underfunded. Each party will gain an advantage over his activity.

So that national development can proceed smoothly through the economy, the banks should be in a safe position and away from the risk of loss because the bank is one pillar of the business capital. However, in practice, banks are always faced with the risk, especially in the disbursement of funds. This situation is illustrated by the presence of nonperforming loans (NPL ratio is high). The condition is certainly influenced by factors that influence it, including macroeconomic variables that have an impact on many sectors including the financial sector banks. The hope is macroeconomic variables as a result of market mechanisms or due to monetary policy made by the central bank is able to improve the economy of the country so that these conditions ultimately impact the bank's declining financial risk.

Indonesia's banking system used is a dual banking system. With so measures was taken by Bank Indonesia is different for the two types of banks. Islamic bank does not know the interest system so that profits can be sourced from a profit share in the results of the businesses that use the funds of Islamic banks as well as investments of Islamic banks themselves (Antonio, 2001). Therefore, there are some terms that differ between the two types of banks. In Islamic banking credit terms replaced with financing so that the ratio of non-performing loans (NPL) is replaced by the ratio of nonperforming finance (NPF).

To know the condition of NPL and NPF in Indonesia Banking can be seen in the following graph:

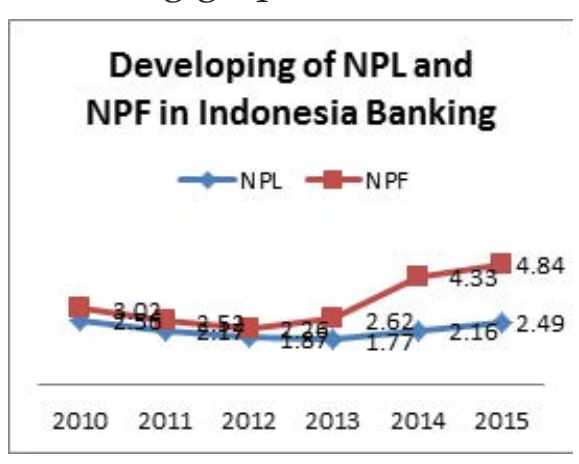

Figure 1: Developing of NPL and NPF in Indonesia Banking

From figure 1, we can see that nonperforming finance in Islamic bank is higher than nonperforming 
loan conventional bank this is a sign that current state of Islamic banks has a high risk to the funds disbursed. So it must be known the factors that cause the high ratio of nonperforming loan/finance.

Thehighnonperforming loan banking is certainly influenced by external factors mainly macroeconomic conditions. Hakim (2017) states that macroeconomic condition has influence on non performing loan. Sudiyatno (2010) states that inflation, interest rates, and economic growth are macroeconomic variables that are often seen as factors that influence the decision of capital market participants. These variables have the potential to improve or degrade the performance of the company, either directly or indirectly. Sudiyatno (2010) also explained that the macroeconomic fundamentals are a reflection of the systematic risk. Deteriorating macroeconomic conditions will increase the systemic risk which can reduce the performance of the company, and vice versa. Therefore, we can conclude that the macroeconomic conditions can be predicted as factors that affect the financial risk of the bank. Where the financial condition of one of them can be proxied by the NPL ratio decreasing the performance of the bank as a mirror. Samsul (2006) found that changes in macroeconomic factors will not immediately affect the company's performance but slowly and in the long term.

Several studies in Indonesia show different results regarding the macroeconomic conditions in the financial performance of banks, in particular, affect the performance of lending. Rahmawulan (2008), to found results, that GDP significant positive effect on nonperforming loan (NPF). Soebagia (2005) found that GDP no significant effect on of nonperforming loan (NPF). However, changes in the exchange rate and inflation have a significant impact on nonperforming loan (NPL). Arya (2010) found that inflation is not a significant impact on the change in the NPL. Mutamimah and Chasanah (2012) found that GDP positive effect on exchange rate but not significant to the NPF, but inflation negatively affect on NPF.

While the research results outside Indonesia are as follows:ThestudybyShu(2002) found that nonperforming loan in Hong Kong has a negative correlation with GDP growth and inflation. But it has a positive relationship 
with the level of interest rate. Results Farhan et al. (2012) conducted in Pakistan, found suitability perception that non-performing loan (NPL) of the banking sector had a positive correlation with the level of interest rate, inflation, and exchange rate while GDP growth has a significant negative correlation with problem loan. Results of research by Salas and Saurina (2002) in Spain, found that the factors that determine the problem loans are high interest rates, GDP growth conditions, and soft loans. Hoggarth research results, et al (2005) in the United Kingdom found that inflation and interest rate have a positive relationship with the credit crunch. Bofondi research results and Ropele (2011) in Italy, found that nonperforming loan is positively related to the level of borrowing and negatively related to the rate of growth of Gross Domestic Product.

Departing from the need to be known about the factors that affect the nonperforming loan of banks in particular of macroeconomic variables, and still the diversity of research findings of the factors that affect nonperforming loan banks both conducted in Indonesia and internationally, This requires re-examination with up to date data to complete the current research gap. So, it is through this study will be tested again on the impact of macroeconomic variables either as a result of monetary policy as well as a result of market mechanisms on the nonperforming loan of banks. Monetary policy instruments were tested namely Indonesian bank certificates/sharia Indonesian bank certificates and interest rates, while the macroeconomic variables as a result of market mechanisms, namely exchange rates, inflation, and GDP. In this study also will be compared to both types of banks in Indonesia which conventional banks and Islamic banks with the efficiency ratio as a control variable. The efficiency ratio is used as a control variable because efficiency is a very important factor for banks. An efficient bank means paying close attention to every cost incurred should be maximized revenue. This is as one of the differentiators of research that has been done.

So that will be found the comparison of financial strength between Syariah bank and the conventional bank over macroeconomic disorder by considering the efficiency of each bank because the macroeconomic condition can not be avoided so it must get special attention. 
Therefore, the results of this study can be an evaluation material for each bank of both types of banks in the face of external circumstances (macroeconomics) and also for Bank Indonesian as the central bank on the impact of policies issued to the high nonperforming loan.

\section{LITERATURE REVIEW}

Yardstick of the success of bank management is to look at the financial performance. The better the bank's financial performance it showed in a safe condition. The entire management of the bank, both of which include capital management, asset quality management, general management, profitability management and liquidity management will eventually influence and lead to the profitability on a banking company (Payamta, 1999).

Indicators of the poor financial condition of banks are the amount of nonperforming loan ratio (financial risk). If this ratio is greater then it indicates a performing of the bank is not good. The level of bank business continuity is closely related to its productive assets, therefore the bank's management is demanded to be able to monitor and analyze the quality of earning assets owned. The quality of earning assets showed asset quality with respect to the credit risk faced by banks due to the credit and investment bank fund. Earning assets quality assessed include the investment of funds in rupiah or foreign currency, in the form of loans and securities (Siamat, 2005). Credit risk accepted by the bank is one of the bank's business risk, resulting from nonpayment not back loans granted by the bank to the debtor. Therefore, credit management capabilities urgently needed by the bank concerned (Sinungan, 2000). Nevertheless, the level of problems that occur in the bank would not only result from the bank's internal factors but external factors that are difficult to avoid.

To determine the NPL can be seen in the ratio of the nonperforming loan (NPL) in conventional banks and the ratio of nonperforming finance (NPF) in Islamic banks. The ratio allowed by Bank Indonesia amounted to 5\%. If the ratio is greater than $5 \%$ it is considered that the bank does not meet the category of healthy banks.

Some macroeconomics factors suspected to affect the nonperforming loan consist of Bank Indonesia Certificates (BIC), interest rate, exchange rate, inflation and Gross 
Domestic Product (GDP).

Bank

Indonesia

Certificates (BIC) are securities issued by Bank Indonesia in recognition of short-term debt (1-3 months) with a discount/flowers Bank Indonesia Certificates is one of the mechanisms used by Bank Indonesia to control the stability of the rupiah and expressed as a percent. Meanwhile, Sharia Bank Indonesia Certificates (SBIC) are securities based on Sharia Principles in the short-term rupiah currency issued by Bank Indonesia (BI). Application of this Sharia Bank Indonesia Certificates made since the enactment of the PBI No. 10/11/PBI/2008 on March 31, 2008. Prior to the regulation set, securities based on sharia principles used by BI is Wadi'ah Bank Indonesia Certificates. Wadi'ah Bank Indonesia Certificates and Sharia Bank Indonesia Certificates expressed as a percent. Issuance of $\mathrm{BIC}$ or SBIC by Bank Indonesia is intended to address the problem of the country's economy in particular deal with the excess amount of money in circulation. Because if the money supply too much will make the rupiah is not stable and will continue to weaken. The result is the power of the public economy into decline and will eventually have an impact on banks' risk on the money stored in the society. So that the public's ability to restore the funds to be decreased and at the same bank will increase bad loans. According to research conducted by Sipahutar (2007) and Rahmawulan (2008) that when the government raised interest rates BIC followed by conventional banks to raise interest rates on credit, the customer will have difficulty paying their credit coupled with interest rates higher and higher so that NPL will increase. This has been supported by research Zeman and Jurca (2008), Barajas et al (2008), Rahmawulan (2008), Iqbal (2008) and Simon (2012). Through this research will be shown to be back on the impact of the issuance of BIC/SBIC on the nonperforming loan of the bank.

The interest rate is the price that is willing to pay out of the use of money for a certain period (Kurniawan, 2004). Monetary policy through the interest rate of Bank Indonesia (BI) is crucial to the benefits and risks of a bank. Conventional Bank will determine the interest rate follows the $\mathrm{BI}$ rate so that conventional banks have a foothold in order to rescue its financial condition in the midst of uncertain 
economic conditions. Unlike the Islamic banks to determine the benefit based on the concept for the results, so it takes a good management in addressing risks. However, the necessary verification as to whether interest rates have an impact on the quality of Islamic bank financing, given the Islamic bank under the auspices of Bank Indonesia and can not be denied that people are still comparing the benefits and risks of choosing a conventional bank or Islamic banks. Therefore, to determine the effect of monetary policy through the interest rate (BI rate) to NPL of the bank so research is conducted. Data of previous studies show that the research results Setiawan and Sherwin (2017), Shu (2002), Hoggarth, etal (2005), Salas and Saurina (2006), Bofondi and Ropele (2011) and Farhan et al (2012) found that interest rates have a positive relationship with the nonperforming loan. This means that the higher the interest rate will increase nonperforming loan.

The exchange rate is the price of the domestic currency to foreign currencies (foreign). The exchange rate is the exchange rate of foreign currencies against the currencies of Indonesia which describes economic stability in the country of Indonesia.
Exchange rate caused partly because of the export-import mechanism which will form the rupiah. In this study, the exchange rate used is the rupiah to US dollar. If the exchange rate to US dollar is getting stronger then shows Indonesia country's economy in good condition. It leads to increased activity of the company because it is not burdened with the severity of the exchange rate, especially for companies that rely on raw materials imported. Therefore, if the exchange rate to US dollar strengthened tendencies customers will be easier to repay the loan. These conditions would benefit banks because it will increase profits and improve ROA. Conversely, if the exchange rate decreases then the customer has the heavy burden and the tendency will happen loans (NPL/NPF). Research conducted by Firdaus (2017), Soebagia (2005) and Farhan et al. (2012) found that the exchange rate had a significant impact on a nonperforming loan (NPL). But unlike Mutamimah and Chasanah (2012) who found that the exchange rate has a positive effect but not significant to the NPF.

Inflation is the tendency for an increase in the price of the products 
as a whole. High inflation rates usually associated with economic conditions too hot (overheated). That is, the economy experienced a demand for a product that exceeds the capacity of its product offerings, so prices tend to rise. Inflation is too high will cause a decrease in the purchasing power of money. With the decline in the purchasing power of the feared would reduce the ability of customers to repay their debts. The impact is will raise the ratio of nonperforming loan (NPL/NPF). Soebagia (2005), Hoggarth, et al (2005) and Farhan et al. (2012) found that inflation is a significant impact on problem loans. In contrast to Firdaus (2017), Shu (2002) and Mutamimah and Chasanah (2012) who found that inflation negatively affects the NPF. But unlike Arya (2010) found that inflation is not a significant impact on the NPL. So did the research Firmansyah (2014) found that when people declining purchasing power does not diminish the public turned out to pay off the debt obligations in financing.

\section{Gross}

Domestic Product (GDP) is a measure of the advance of the country's economy as shown by the number of goods and services produced by the company. If GDP increases, as a measure of improved earnings and economic conditions in good condition. Therefore, it would affect the ability of customers to repay their loans. Conversely, if the poor economic conditions, the ability of customers to fulfill their obligations will be correspondingly reduced. Thus the impact is banks as the lenders will increase bad loans outstanding that cause a rise of the nonperforming loan. With the increase of nonperforming loan will decrease financial performance. Rahmawulan (2008) and Salas and Saurina (2006) found that GDP positive effect on problem loans. While Shu (2002), Bofondi and Ropele (2011) and Farhan et al. (2012) found that nonperforming loan had a negative correlation with GDP growth. In contrast to Soebagia (2005) and Mutamimah and Chasanah (2012) who found that GDP does not affect the problem loans. These differences cause important to research done back in order to find the most convincing answer on the impact of the GDP on the NPL of the bank.

In this study also used a variable control namely banking efficiency. Banking efficiency as measured by the ratio of Operating Expenses to Operating Income (OEOI), was used as a control variable in predicting the effect of 
macroeconomic indicators on the occurrence of the bad loan. This is because OEOI closely related to the operational of the bank. Operational costs are too high to inhibit the high bank profits. While the bank's high income with low operating costs can make the condition of banks are in a healthy position, which means an inclination to minimize the occurrence of bad credit can be overcome.

Based on theory and results studies, the framework of this research can be described as follows: consists of NPL and NPF taken from BI through Indonesia Banking Statistics and Islamic Banking Statistics.

2. Independent variable consists of BIC/SBIC, $\mathrm{BI}$ rate and inflation are taken from a website that is www.bi.go.id and GDP are taken from a statistics central agency.

3. Control Variables is efficiency is taken from BI through Indonesia Banking Statistics and Islamic Banking Statistics.

Mechanical analysis

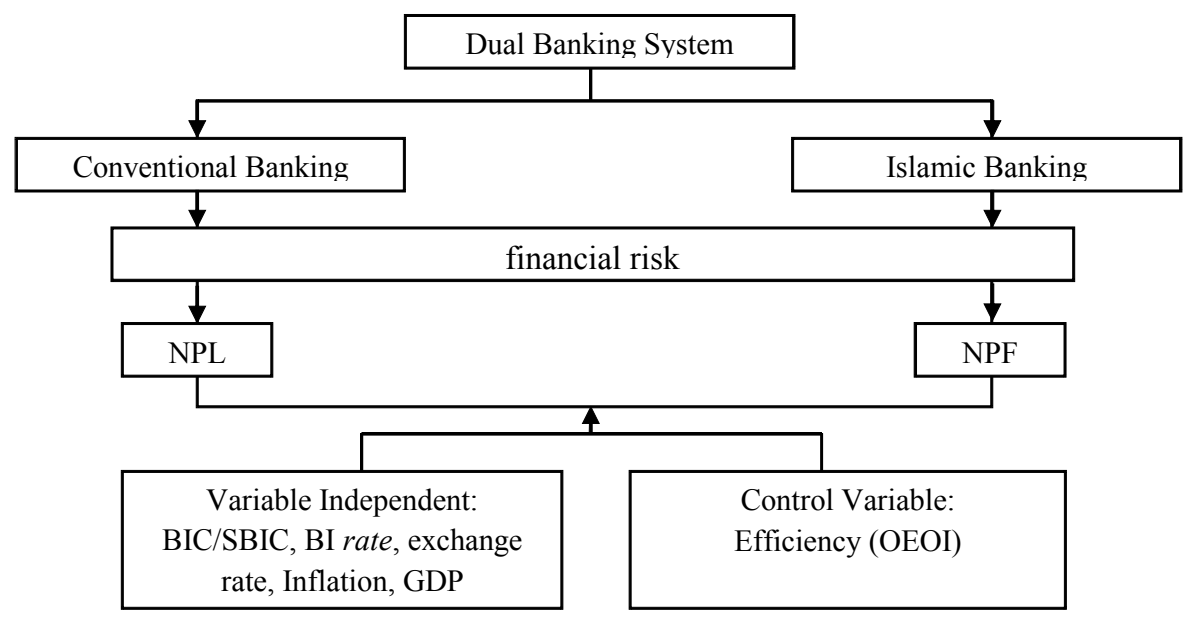

Figure 2. Framework

\section{RESEARCH ETHODOLOGY}

In this study, the population is around the conventional banks and Islamic banks in Indonesia in the period of 2010 to 2016 using quarterly data.

1. The dependent variable using multiple regression analysis to test all research model. There are two models of the research is as follows:

1. Model to test the effect of macroeconomic to NPL of conventional bank $\mathrm{NPL}=\mathrm{a}+\mathrm{b} 1 \mathrm{BIC}+\mathrm{b} 2$ 
BI_rate + b3 exch_rate+ b4 $\mathrm{INF}+\mathrm{b} 5 \mathrm{GDP}+\mathrm{b} 6 \mathrm{EFF}+e$

2. Model to test the effect of macroeconomic to NPF of Islamic bank

$\mathrm{NPF}=\mathrm{a}+\mathrm{b} 1 \mathrm{SBIC}+\mathrm{b} 2$ BI_rate + b3 exch_rate + b4 Where:

$\mathrm{INF}+\mathrm{b} 5 \mathrm{GDP}+\mathrm{b} 6 \mathrm{EFF}+e$

NPL/NPF $=$ Non performing loan/Non Performing Finance, $\mathrm{BIC}=$ Bank Indonesia Certificate, SBIC $=$ Sharia Bank Indonesia Certificate, BI_rate = Bank Indonesia rate, Exch rate $=$ exchange rate Rupiah to US Dolar, INF = Inflation, GDP $=$ Gross Domestic Bruto, EFF = Efficiency using Operational Expenses to Operational Income, $e=$ error .

The test results of this study are influenced by the value of the variable coefficient significance is concerned. The conclusion the study results are based on t-test to test the significance of the influence of the independent variables on the dependent variable with the significance level of $5 \%$ (0.05). While the F-test ( $F$ test) was used to test the accuracy of the regression model. Hypothesis testing is done if it meets the test quality data through the classical assumption test of normality test, heteroscedasticity, autocorrelation and multicollinearity test. The data in this study will be processed using IBM SPSS ver. 21.0 for windows.

\section{RESULT AND DISCUSSION Result}

On data collected in accordance with the criteria of the research is research in conventional banks and Islamic banks, then test the data quality to ensure data is worthy of testing the hypothesis. The results of data quality analysis of conventional banking are presented in Table 1 and Table 2 below:

Table 1. Normality, autocorrelation, and Heteroskedasticity of Conventional Bank Data

\begin{tabular}{ccc}
\hline \multicolumn{3}{c}{ Classic Assumption Test } \\
\hline $\begin{array}{c}\text { Kolmogorov-Smirnov } \\
\text { Test }\end{array}$ & Asymp. Sig. (2-tailed) & 0.200 \\
\hline Durbin-Watson & & \\
\hline Glejser Test & Sig. BIC & 1.849 \\
& B__rate & 0.323 \\
& Exch_rate & 0.895 \\
& Inflation & 0.614 \\
& GDP & 0.850 \\
& EFF & 0.988 \\
& & 0.195 \\
\hline
\end{tabular}




\begin{tabular}{cc}
\hline TOL. BIC & 0,231 \\
BI_rate & 0,139 \\
Exch_rate & 0,474 \\
Inflation & 0,124 \\
GDP & 0,214 \\
EFF & 0,392 \\
\hline
\end{tabular}

Source: Output IBM SPSS (Data processed)

The results of data the value of DW is an area that normality test of conventional is free of autocorrelation.

banking can be seen in Table 1. Based on the output Kolmogorov-Smirnov test and produce value Asymp. Sig (2-tailed) is 0.250 . This value is greater than 0.05 or $5 \%$. It can be concluded that the data are expressed in the normal distribution.

Results

autocorrelation analysis of conventional banking data in Table 1, the value of DurbinWatson (DW) of 1.849. Based on the output Durbin-Watson (DW) with $\mathrm{k}=6$ and $\mathrm{n}=28$ then the value of $\mathrm{dL}=0,9505$ and $\mathrm{dU}$ $=1,9585$, then a $4-\mathrm{dU}=2,0415$ and $4-\mathrm{dL}=3,0495$. Therefore

Table 2. Normality, Autocorrelation and Heteroskedasticity Test of Islamic Banking Data

\begin{tabular}{lcc}
\hline \multicolumn{3}{c}{ Assumption Classic Test } \\
\hline Kolmogorov-Smirnov Test & Asymp. Sig. (2-tailed) & 0.200 \\
\hline Durbin-Watson & & 1.257 \\
\hline Glejser Test & Sig. SBIC & 0.987 \\
& BI_rate & 0.919 \\
& Exch_rate & 0.480 \\
& Inflation & 0.846 \\
& GDP & 0.878 \\
& EFF & 0.264 \\
\hline
\end{tabular}




\begin{tabular}{cc}
\hline TOL. SBIC & 0,245 \\
BI_rate & 0,123 \\
Exch_rate & 0,573 \\
Inflation & 0,125 \\
GDP & 0,155 \\
EFF & 0,325 \\
\hline
\end{tabular}

Source: Output IBM SPSS (Data processed)

Results of data normality test of Islamic bank can be seen in Table 2. Based on Kolmogorov-Smirnov test output and generate value Asymp. Sig (2-tailed) is 0.200 . This value is greater than 0.05 or $5 \%$. It can be concluded that the data are expressed in normal distribution.

\section{Results}

autocorrelation analysis of conventional banking data in Table 2, the value of DurbinWatson (DW) of 1.257. Based on the output Durbin-Watson (DW) with $\mathrm{k}=6$ and $\mathrm{n}=28$ then the value of $\mathrm{dL}=0,9505$ and $\mathrm{dU}$ $=1,9585$, then a $4-\mathrm{dU}=2,0415$ and $4-\mathrm{dL}=3,0495$. Therefore the value of DW is an area that is free of autocorrelation.

Theresults of Glejser test of Islamic bank data in Table 2 , known sig. all independent variables more than greater than 0.05. This means that no heteroskedasticity in regression models in this study.

The result of multicollinearity test of Islamic bank shows the average TOL value is above 0,1 . This shows the regression model freed from multicollinearity between independent variables.

Based on data analysis result of classical assumption of conventional banking and Islamic banking of data it can be concluded that data are suitable for use in multiple regression analysis. In analyzing the data in this study conducted with IBM SPSS ver. 21.

The first step is to know the accuracy of the model (goodness of fit) the influence of the independent variable (BIC/SBIC, BI_rate, exchange rate, inflation, GDP, and efficiency) on the dependent variable (NPL) then F test.

Table 3. Output F test

\begin{tabular}{lllll}
\hline \multirow{2}{*}{ Model } & \multicolumn{2}{l}{ Conventional Banking } & \multicolumn{2}{l}{ Islamic Banking } \\
\cline { 2 - 5 } & $\mathrm{F}$ & Sig. & $\mathrm{F}$ & Sig. \\
\hline & 16,156 & 0.000 & 10,030 & 0.000 \\
\hline
\end{tabular}

Source: Output IBM SPSS (Data processed) 
Based on Table 3 level was set at $5 \%$ or 0.05 . showed that the value of sig. The following are the effect of both models are 0.000 . This value is smaller than the limit value sig. $(\alpha=0.05)$. Therefore, the results of this study indicate that in order to explain the variable debt loans (NPL/ $\mathrm{NPF}$ ), then the variable BIC/ SBIC, BI_rate, exchange rate, inflation, GDP, and efficiency can be used together because the model is fit for use.

Furthermore, to determine the effect of the independent variable (BIC/ SBIC, BI_rate, Exchange Rate, Inflation, GDP, and efficiency) on the dependent variable (NPL/NPF) using t-test. Based on test results by using multiple regression analysis obtained the following results: each independent variable in predicting the condition of the power of financial performance as measured by the quality of credit (financing).

\section{Discussion}

- Impact BIC/SBIC On NPL/NPF

The analysis showed that the sig. BIC is 0.740 (> 0.05), it means BIC not affect on NPL conventional banks, and also sig. SBIC is 0.093 (> 0.05), it means SBIC affect the NPF Islamic banks.

From these results indicate that monetary policy set by BI through the rise and decline of BIC/SBIC will not affect the NPL but affect to NPF

Table 4. Output t-Test

\begin{tabular}{lrrrr}
\hline Variable & \multicolumn{3}{c}{ Conventional Banking } & \multicolumn{3}{c}{ Islamic Banking } \\
\cline { 2 - 5 } & $\mathrm{T}$ & Sig. & $\mathrm{t}$ & Sig. \\
\hline BIC/SBIC & $-0,337$ & 0,740 & 1,760 & $0,093^{* *}$ \\
BI_rate & 0,268 & 0,268 & 0,335 & 0,741 \\
Exch_rate & $-1,357$ & 0,189 & $-0,497$ & 0,624 \\
Inflation & $-0,907$ & 0,375 & $-2,307$ & $0,031^{*}$ \\
GDP & $-1,817$ & $0,084^{* *}$ & $-1,984$ & $0,060^{* *}$ \\
EFF & 6,073 & $0,000^{*}$ & 0,182 & 0,857 \\
\hline
\end{tabular}

*) Signifiant on $5 \%,{ }^{* *}$ ) Signifiant on $10 \%$,

Source: Output IBM SPSS (Data processed)

The results of multiple for the funds disbursed by the regression analysis on the data banks to the public. However, that has been tested the quality this has little impact on the of the obtained answers to level of financial congestion these results. The significance of islamic bank. This happens 
because the central bank in issuing policies intended to attract funds in banks in order to stabilize the amount of money in circulation. If the circulation of money has either the value of rupiah will be stable. Therefore, the impact of what happens is people will be able to pay all of its obligations including the obligation to return the funds to the bank. Thus, measures were taken by the Bank Indonesia through BIC/SBIC it does not interfere NPL of conventional banks and Islamic banks.

\section{- Impact BI Rate On} NPL/NPF

The analysis showed that the sig. BI rate variable on conventional banking amounted to 0.268 ( $>0.05)$, it means that the $\mathrm{BI}$ rate has no effect on NPL conventional banking. Likewise sig. BI rate variable on Islamic banking amounted to 0.741 (>0.05), it means that the BI rate has no effect on Islamic banking NPF.

Based on these results can be explained that the monetary policies issued by $\mathrm{BI}$ through the interest rate of Bank Indonesia (BI rate) will not interfere with the ratio of bad loans in the banking sector both conventional and Islamic banking. This means that the interest rate is not the reason for the growing nonperforming loan ratio, as this has been anticipated by the management of conventional banks to improve the quality of the distribution of funds. The bank's management has succeeded in selecting clients who deserve to be given credit/financing so that the size of the lending rate set by conventional banks, which is derived from the high BI rate will not interfere with the power of the customer to meet its obligations. Likewise, impact on Islamic banks because indirectly that the BI rate will determine the attitude of customers in this field to Islamic bank financing, it turns on the periods of the study did not prove their influence. This is a proof that the concept of profit sharing which is run by Islamic banks have managed to respond well to the community. Therefore it can be concluded that the monetary policy BI by determining the amount of $\mathrm{BI}$ rate does not affect the NPL of the conventional banking and Islamic banking financing quality.

- Impact Exchange Rate On NPL/NPF

The analysis showed that the sig. variable exchange rate at the conventional banks 0.189 (>0.05), it means that the exchange rate has no 
effect on NPL conventional banking. Likewise sig. variable exchange rate on Islamic banking $0.624(>0.05)$ it means that the exchange rate has no effect on NPL Islamic banking.

Based on the results of this study proves that the exchange rate of rupiah to US dollar as a result of a market mechanism, especially due to the flow of export and import goods resulting from the outflow of money from domestic to abroad has no impact on conventional banking and Islamic banking. If the exchange rate rupiah to US dollar rises or vice versa so the ratio of bad loans will not be disrupted. This situation can be illustrated by the conditions in which the exchange rate rupiah to US dollar rises, the prices of goods and services in the country tend to fall. Therefore there will be a very tight price competition that causes the risk of failure of sale. This situation causes the product that has been produced well exploited through export sales because it gives more opportunity to get profit. Thus, the company is able to pay off its credit to the bank so that the risk of congestion for both conventional and Islamic banking becomes non-existent. Vice versa if the exchange rate of rupiah to US dollar is down then the company is able to anticipate with a good strategy so that the condition does not affect its obligation to pay off the debt to the bank so that ultimately does not disrupt the level of a bad loan of banks. This proves that the exchange rate does not affect the ratio of bad loans for both types of banking. So in accordance with the findings of Mutamimah and Chasanah (2012) that exchange rate is influential but not significant to NPF.

- Impact Inflation On NPL/NPF

The analysis showed that the sig. Inflation in the conventional banking variable of $0.375(>0.05)$ it means that the inflation has no effect on NPL conventional banking. While sig. variable inflation on the Islamic banking amounted to $0.031(<0.05)$, with negative direction, it means that inflation has a negative effect on the NPF Islamic banking.

$$
\text { Inflation shows a }
$$

simultaneous price increase and indicates a weakness of the country's economy. However, based on the results of the above analysis, the condition has no impact on conventional banking so that the NPL ratio remains stable. The weak economic condition has been able to be overcome by the society so it does not make the community become unable 
to pay off their debts to the banking system. This result is in accordance with the results of previous research that Arya (2010) found that inflation does not have a significant impact on the NPL. Similarly, research results Firmansyah (2014) conducted on Islamic Rural Bank in Indonesia showed that statistically proved that when people decreased purchasing power, the community did not reduce its obligation in paying its debts.

But unlike Islamic Banking. At the time of inflation so that the economic strength of the community becomes weakened, then the way that is done by Islamic banking when the inflation is still running its activities as usual. So many companies, especially large-scale companies that make large loans and used to increase production. Increased production is what causes sales to increase and the profit gained to increase. Of the large profits, the company is able to repay its loan debt so that the impact on the decreasing level of congestion of Islamic banking. This is resolved because the concept used by Islamic banking is a profitsharing rather than interestbased so as not to incriminate one party, especially customers when the economy is weakening. The results of this study are in accordance with Soebagia (2005), Hoggarth, et al (2005) and Farhan et al. (2012) found that inflation had a significant impact on nonperforming loans.

From the results of this study can be concluded that inflation does not affect anything against NPL of the conventional bank. However, inflation is favorable to Islamic banking because when inflation rises it will lower the ratio of NPF Islamic bank.

\section{- Impact GDP On NPL/ NPF}

The analysis showed that the sig. GDP in the conventional banking variable of $0.084 \quad(>0.1)$, it means GDP negative effect on NPL conventional banking. While sig. GDP in Islamic banking variable of $0.060(<0.1)$, which negative direction, it means that GDP has negative effect on the NPF Islamic banking.

Based on the results of the above analysis, it can be concluded that banking are selective in choosing customers so that with the increase in GDP, the impact on the decline in bad financing either conventional banking or islamic banking. In addition, Islamic banking has run the principle of profit sharing with both which makes the two sides between the Islamic banking 
with customer is not harmed because if the a customer gets profit then the profits are the rights of both parties and if any loss occurs then the risk of loss is borne together. Therefore, higher GDP will lower the NPF ratio. Even if the financing disbursed by Islamic banking using the sale and purchase product then the increase in sales as reflected by the increase in GDP will increase the company's profit also, in the end, the company will be able to pay off its obligations. So that will reduce the ratio of NPF/NPL. The results of this study consist with Shu (2002), Bofondi \& Ropele (2011) and Farhan et. Al. (2012) founds GDP negatively related to problem loans.

- Impact Efficiency On NPL/NPF

This analysis was conducted to determine whether bad loans also affected by the efficiency of the bank. This is based on efficiency, as measured by OEOI is just one part of the financial management to regulate the flow of available cash at the bank. The cash flow of determining the distribution fund to a community.

The analysis showed that the sig. efficiency is 0.000 $(<0.05)$, it means efficiency has positive effect on NPL conventional banking. While sig. efficiency is 0.857 (> 0.05), it means efficiency does not affect on NPF Islamic banking.

From the results of the aboveanalysis can be explained that the amount of the ratio of bad loans determined also by the level of efficiency. The more efficient the smaller the NPL ratio. So conventional banks should always pay attention to any costs incurred and should be able to increase revenue. In contrast to the results of analysis on Islamic bank, there is no impact whatsoever on the efficiency of the NPF ratio. If we synchronize with the result of research of Firmansyah (2014) conducting research at Islamic rural bank in Indonesia that efficiency does not necessarily reduce the nonperforming finance, this is because bad loans are external banking business that directly relates to the society in paying its obligation not depending on the efficiency of banking operational. So that bank efficiency is not a standard of management in taking policy regarding the management of problem loans.

\section{CONCLUSION}

Based on the research that has been conducted that BIC does not effect on the NPL but SBIC effect on the NPF. This means spending policies 
BIC/SBIC by Bank Indonesia will not disturb banking NPL conventional banking but impact on Islamic banking.

BI rate does not affect the NPL/NPF and also BI rate does not affect the NPF. This means that the BI rate will not disturb the credit quality of conventional and Islamic banking so that both types of banks strong enough to withstand the risks of BI rate.

The exchange rate does not affect the NPL and also Exchange rate does not affect the NPF. This means that the exchange rate rupiah to US dollar will not disturb the credit quality of both conventional and Islamic banking.

Inflation does not affect on the NPL but inflation negative effect on the NPF. This shows that inflation does not give anything to the conventional bank but inflation is favorable for Islamic bank because when inflation rises it will lower the ratio of NPF Islamic bank.

GDP negative effect on the NPL and NPF. This means that GDP gives the good impact for conventional and Islamic bank that is lower NPF ratio.

In addition to the above conclusion, there are some suggestions that can author to convey to improve the quality of research in the future, including 1) can be added other macroeconomic indicators as independent variables that predicted effect on the NPL to be known more widely on the impact of macroeconomic variables more to the occurrence of nonperforming loan. 2) The period of only 7 years of research so as to increase the confidence on the research results can be extended research period.

\section{IMPLICATION}

Based on the findings in this study indicates that some macroeconomic variables have a good impact on Islamic banking that are SBIC, inflation and GDP. With rising SBIC, inflation and GDP, the NPF ratio of Islamic banking has declined. Thus, Islamic banking can enjoy the conditions at the time of inflation, at that time all prices are rising and can be said economic conditions are weakening, but the quality of financing is even better, and this is a unique condition. Likewise, when the GDP is rising then the economic condition can be said is good, it turns out this has a good impact on Islamic banking because it can reduce the NPF ratio. Meanwhile, conventional banking is not affected by any of the macroeconomic variables studied. Based on these analyses, the results of 
this study can be used as the material for Bank Indonesia and General Banking concerning macroeconomic policies related to the bank credit quality, that NPF Islamic banking are more sensitive to some macroeconomic conditions compared to NPL conventional bank. 


\section{REFERENCES}

Antonio, Muhammad Syafii. (2001). Bank Syariah dari Teori ke Praktik. Jakarta: Gema Insani Press.

Arya, Wikutama. (2010). Faktor-faktor yang mempengaruhi Nonperforming loan Bank Pembangunan Daerah (BPD). Tesis, at Pascasarjana Programme of Accounting Magister of Indonesia University.

Barajas, Adolfo L.L dan Restrepo, Jorge E. (2008). Macroeconomic Fluctuation and Bank Behavior in Chile. Revisa de Analysis Economico. Vol. 23 (2). Chile: Central Bank of Chile.

Bofondi, M. and Ropele, T. (2011). Macroeconomic Determinants of Bad Loans: Evidence From Italian Banks. Banca d'Italia Occasional Papers. No. 89.

Dwipartha, N. M. W. (2013). Pengaruh Faktor Ekonomi Makro dan Kinerja Keuangan Terhadap Nilai Perusahaan Manufaktur di Bursa Efek Indonesia. Economics Faculty of Udayana University.

Farhan, Muhammad et. al. (2012). Determinants of NonPerforming Loans: Perception of Pakistani Bankers. European Journal of Business and Management. 2012. ISSN 2222-1905 (Paper) ISSN 2222-2839 (Online) Vol 4 (19).

Irdaus, Novia (2017). Analisis Determinan Non Performing Loan pada Bank Umum Konvensional di Indonesia. Tesis at Universitas Negeri Yogyakarta.

Firmansyah, Irman. (2014). Determinant of Nonperforming loan: The Case of Islamic Bank in Indonesia". Buletin Ekonomi Moneter Perbankan. Vol. 17 (2).

Ghazali, Imam. (2013). Aplikasi Analisis Multivariate dengan Program IBM SPSS 21. Semarang: BP Diponegoro University.

Hakim, Arif Rahman (2017). “Pengaruh Kondisi Ekonomi Makro dan Proses Manajemen Resiko Kredit terhadap Non 
Performing Loan". E-Journal. Fakultas Ilmu Administrasi Universitas Brawijaya. Vol 11 (2).

Hoggarth, Glenn; Sorensen, Steffen dan Zicchino, Lea. (2005). Stress tests of UK banks using a VAR approach. Bank of England Working Paper. No. 282, ISSN 1368-5562.

Iqbal, Muhammad. (2008). Perbandingan Faktor-Faktor yang Mempengaruhi Pembiayaan Bermasalah pada Perbankan Syariah dan Perbankan Konvensional. Tesis PSKTTI-UI. Jakarta.

Kurniawan, T. (2004). Determinan Tingkat Suku Bunga Pinjaman di Indonesia Tahun 1983-2002. Economics Faculty of UNS Surakarta.

Mutamimah dan Chasanah, Siti N. Z. (2012). Analisis Eksternal dan Internal dalam Menentukan Non Performing Financing Bank Umum Syariah di Indonesia". Jurnal Bisnis dan Ekonomi. Vol. 19 (1), pp. 49-64.

Payamta, Machfoed. (1999). Evaluasi Kinerja Perusahaan Perbankan Sebelum Menjadi Perusahaan Publik Di Bursa Efek Jakarta (BEJ). Kelola, No. 26/VIII.

Poetry, Zakiyah Dwi dan Sanrego, Yulizar D. (2011). Pengaruh Variabel Makro dan Mikro terhadap NPL Perbankan Konvensional dan NPF Perbankan Syariah. Islamic Finance \& Business Review. 2011. Vol. 6 (2).

Rahmawulan, Yunis, (2008). Perbandingan Faktor Penyebab Timbulnya NPL dan NPF Pada Perbankan Konvensional dan Syariah di Indonesia. Tesis, at Pascasarjana Programme of Accounting Magister of Indonesia University.

Salas, Vincente dan Jesus Saurina. (2002). Credit Risk in Two Institutional Regimes: Spanish Commercial and Savings Banks. Journal of Financial Services Research, Vol. 22 (3), pp. 203-224.

Samsul, M. (2006). Pasar Modal E Manajemen Portofolio. Surabaya: Erlangga. 
Setiawan, Chandra and Sherwin, Selly Magdalena (2017). "Bank Efficiency and the Determinants of Non-Performing Finance of Full-Fledged Islamic Banks in Indonesia". Proceedings of $12^{\text {th }}$ Asia-Pacific Business Resarch Conference, Concorde Hotel, Kuala Lumpur.

Shu, C., (2002). The Impact of macroeconomic environment on the asset quality of Hong Kong's banking sector. Hong Kong Monetary Authority Research Memorandums. 2002.

Siamat, Dahlan. (2005). Manajemen Lembaga Keuangan, Edisi Keempat, BP Economics Faculty of Indonesia University. Jakarta.

Simon, Arief Budiman. (2010). Analisis Dampak Terjadinya Shock Variabel Moneter terhadap Nonperforming loan Ratio di Indonesia". Article at Kajian Stabilitas Keuangan Bank Indonesia. No. 14 March 2010.

Sinungan, Muchdarsyah. (2000). Manajemen Dana Bank. Edisi Kedua. Jakarta : PT. Bumi Aksara.

Soebagia, Hermawan. (2005). Analisis Faktor-Faktor Yang Mempengaruhi Terjadinya Nonperforming loan (NPL) Bank Umum Komersial: Studi Empiris Pada Sektor Perbankan di Indonesia. Tesis, at Pascasarjana Programme of Magister Management of Diponegoro University.

Sudiyatno, B. (2010). Peran Kinerja Perusahaan dalam Menentukan Pengaruh Faktor Fundamental Makroekonomi, Risiko Sistematis, dan Kebijakan Perusahaan Terhadap Nilai Perusahaan. Tesis, at Pascasarjana Programme of Magister Management of Diponegoro University.

Zeman, Juraj dan Pavol Jurca. (2008). Macro Testing of the Slovak Banking Sector. National Bank of Slovakia". Working Paper 1/2008. 